TAPROBANICA, ISSN 1800-427X. October, 2009. Vol. 01, No. 02: pp. 107-110, pl. 1.

(C) Taprobanica Nature Conservation Society, 146, Kendalanda, Homagama, Sri Lanka.

\title{
STATUS AND MICROHABITAT PREFERENCE OF Otocryptis beddomii BOULENGER, 1885 (REPTILIA: AGAMIDAE) IN PONMUDI HILLS, WESTERN GHATS, KERALA, INDIA
}

\author{
S. R. Chandramouli
}

Department of Zoology, Division of Wildlife Biology, A.V.C. College, Mannampandal, Mayiladuthurai, Tamil Nadu, India; Email: findthesnakeman@gmail.com

\begin{abstract}
The population of Otocryptis beddomii in Ponmudi Hills of Kerala, India was examined to assess its status and microhabitat preference. The encounter rate was significantly higher in pristine habitat (3.51 sightings $/ \mathrm{km})$ than in disturbed habitat $(0.97$ sightings $/ \mathrm{km})$. Sighting frequency was highest in rainforests (60) of mid-altitude (68) and the most-utilized substrate was leaf litter (79.2\%). Disturbances due to human activities had a significant (Proportion test; $\mathrm{z}=2.93, \mathrm{p}<0.05$ ), adverse impact on its population.
\end{abstract}

Keywords: sex ratio, encounter rate, substrate, altitudinal distribution, habitat quality

\section{Introduction}

Otocryptis beddomii Boulenger, 1885, is a mesicforest dwelling terrestrial agamid, endemic to southern Western Ghats, distributed in the states of Kerala and Southwestern Tamil Nadu, India (Das, 2002; Inger et al., 1984; Ishwar et al., 2003; Kumar et al., 2001; Murthy, 1985; Smith, 1935). The large concentrations of the earlier studies on South Indian agamids were on arboreal forms (Bhupathy \& Kannan, 1997; Ishwar et al., 2003; Kumar et al., 2001). Otocryptis beddomii being the only ground dwelling agamid, occurring in the rainforests of Western Ghats, was the least studied. Bhupathy \&
Kannan (1997) have recommended status assessment for this species, based on its absence in their extensive survey throughout southern Western Ghats. Studies on this species were done by Murthy (1980), Daniels (1991) and Joce et al. (2007). This species has been included under "Vulnerable" category of IUCN, by Molur \& Walker (1998). The present study focuses on its status and microhabitat preference in Ponmudi Hill range.

Study Area: Ponmudi Hills ( $\left.8^{\circ} 45^{\prime} \mathrm{N}, 77^{\circ} 08^{\prime} \mathrm{E}\right)$, lying below the Senchottah gap of Western Ghats, 
is in Thiruvananthapuram District of Kerala State, bordering Kalakkad Mundanthurai Tiger Reserve, Tenmala hills and Neyyar, Peppara and Shendurney Wildlife Sanctuaries, has been declared as a 'Reserve Forest', under 'Ponmudi Ecotourism Project'. Elevation varies from 107-1090 m a.s.l. River Kallar is the noteworthy perennial water body. Monoculture plantations like tea, coffee and cardamom exist at higher altitudes and the magnitude of human activities here is high due to pressure exerted by tourism. Rainforests (RF), moist deciduous forests (MDF) and Myristica swamp forests (MSF) are the major vegetation types apart from montane grasslands occurring above $1000 \mathrm{~m}$ a.s.l.

\section{Materials and Methods}

This study was carried out for a span of four months from December 2008 to March 2009. The hill range was stratified into three altitudinal blocks, i.e., low (107-300 $\mathrm{m}$ a.s.1.), mid (300-600 $\mathrm{m}$ a.s.1.) and high (600-1090 m a.s.1.) with a Garmin 12 channel Global Positioning System. Visual Encounter Survey method (Campbell \& Christman, 1982) was employed to collect data. To quantify the results, fixed-length path transects of $500 \mathrm{~m}$ length, of varying width and angles were selected which were not in a straight line. Thirty such transects were examined in each altitudinal block using a pedometer (LC-250 m). Transects without sightings were referred to as blank transects. Of the 90 transects examined, 45 were in pristine habitats and 45 were in disturbed habitats. Surveys were conducted between 8:30 hrs and 17:00 hrs. Encounter rate of the target species was determined using the formula, Encounter rate = sighting frequency/total distance surveyed. For an acceptable interpretation, the result, thus obtained was expressed as the distance needed to be covered to obtain one sighting. Habitat type allocation follows Sasidharan (2004) and habitat qualities were defined based on the magnitude of anthropogenic activities and disturbances. The number of transects in each habitat type varied according to their relative availability. On sighting an individual of the target species, sex (based on colouration, and obvious secondary sexual characters such as presence or absence of hemipenal bulge near the tail base, gular sac indicated by a longitudinal fold of skin); age class (based on approximate length); substrate on which the animal was sighted; temperature and humidity were recorded. Substrates were broadly classified into six categories namely bare ground, leaf litter, rocks, fallen logs, tree base and shrub. Proportion test was carried out to determine the impact of habitat disturbances on this species.

\section{Results (see Pl. 5: Fig. 1-7)}

From 90 transects, 101 sightings were obtained, out of which 40 were adult males, 33 were adult females and 28 were juveniles. The overall encounter rate was 2.24 sightings $/ \mathrm{km} \quad(0.4$ $\mathrm{km} /$ sighting). Of the 90 transects examined, 15 in pristine and 35 in disturbed habitats were blank in each category respectively. Of the 90 transects, 56 were in rainforests, 33 in moist deciduous forests and one in Myristica swamp forest type with 31, 19 and 0 transects being blank in the respective forest types. Seventy nine sightings (29 adult males, 26 adult females and 24 juveniles) were from pristine transects, with an encounter rate of 3.51 sightings $/ \mathrm{km}(0.28 \mathrm{~km} /$ sighting $)$; whereas, only 22 (11 adult males, 7 adult females and 4 juveniles) were from disturbed transects with a comparatively lower encounter rate of 0.97 sightings $/ \mathrm{km}$ (1.03 $\mathrm{km} /$ sighting). Proportion test revealed that, anthropogenic disturbances had a significant impact on the examined population in each altitudinal block $(\mathrm{z}=2.93, \mathrm{p}<0.05)$. Altitudinal distribution was extensive, i.e., $110-1018 \mathrm{~m}$ a.s.l. Most of the sightings $(\mathrm{n}=68)$ were from the mid altitude block, followed by 24 in lower altitude block and 9 from the higher altitude block. Sixty sightings were from rainforests, 39 from moist deciduous forests and 2 from Myristica swamps. Anthropogenic disturbances in rainforests affected the population adversely than in other habitats $(\mathrm{z}=363.52 ; \mathrm{p}$ $<0.05)$. Leaf litter was the most used substrate $(79.2$ $\%$ ), followed by rocks (5.94 \%), fallen logs (4.95\%), tree base (3.96\%) and $2.97 \%$ each on bare ground and shrubs. The maximum perch height recorded was about 2 feet above the ground. Utilization of the above substrates revealed no specific, age or sex dependent preference. Ambient factors namely temperature and humidity varied extensively. Most $(n=43)$ were from the lower temperature block, i.e., $23-25{ }^{\circ} \mathrm{C}$, closely followed by 38 from $26-28{ }^{\circ} \mathrm{C}$ range, and a relatively low number $(\mathrm{n}=20)$ from the higher temperature block, i.e., $29-31{ }^{\circ} \mathrm{C}$. Similarly, the bulk $(\mathrm{n}=56)$ was from the humidity range of $70-80 \%$; 22 from $60-70$ $\%$ range, 13 from $80-90 \%$ range and 10 from $>90 \%$. Sympatric competitors (diurnal, terrestrial insectivorous lizards) to this species like Eutropis macularia and juvenile Calotes elliotti were observed during the study. No instance of either natural predation or roadkill of this species was recorded. Morphology of the individuals sighted was in accordance with literature, except in two 
adult males (fig.1), which had an abnormal, crestlike ridge on the dorsum, with a distinct depression in the nuchal region. Females were larger than males.

\section{Discussion}

Distribution of Otocryptis beddomii in the hill forests of Western Ghats, South of Sencottah gap $\left(9^{\circ}-8^{\circ} \mathrm{N}\right)$ is well known (Das, 2002; Inger et al., 1984; Ishwar et al., 2003; Jose et al., 2007; Kumar et al., 2001; Molur \& Walker, 1998; Murthy, 1985; Smith, 1935). Apart from this, the single sighting record of this species from Kodaikkanal $(>2000 \mathrm{~m}$ a.s.l; $\left.10^{\circ} \mathrm{N}\right)$ by Murthy (1980) is highly inconsistent with all the above-cited literature records, owing to the high altitude and latitude of his locality. My results strongly corroborate the sexual dichromatism patterns reported by Inger et al., (1984) as fresh free ranging specimens of high frequency $(\mathrm{n}=101)$ have been examined. Jose et al. (2007) reported a specimen with unusual colouration i.e., the pale vertebral stripe being closer to grey than buff and the flanks being closer to black than brown. Individuals with such colouration were not recorded during this study. But, the presence of nuchal fold (crest-like dorsal ridge, with a depression in the nuchal region) recorded in two adult males here, has not been reported in this species so far. However, this phenomenon has been documented in its congener O. wiegmanni (see Buhle, 1983; Manthey, 1981, 1985; Matuschka, 1978). The presence or absence of regular dark chevron markings on the dorsum was highly variable as described by Das (2002), Murthy (1985) and Smith (1935). Smith (1935) states that, its types were collected by Colonel Beddome at Sivagiri Ghat, at an altitude of 4,300 feet $(1311 \mathrm{~m})$ elevation. The record of Kumaret al. (2001) from Rosemala and Palaruvi forests of Thenmala at higher elevation has been cited by Jose et al., (2007) without a clear interpretation of any altitude range value. Murthy (1980) has given the highest ever altitude ( $>2000 \mathrm{~m}$ a.s.1.; in Kodaikkanal, $10^{\circ}$ N) from which this species has been recorded. This dubious record deserves further investigation, which will be discussed elsewhere. Molur \& Walker (1998) provide a very wide altitudinal range of 100-2000 m a.s.l, perhaps inclusive of Murthy's (1980) record. Inger et al. (1984) provide even more precise altitudinal distribution range from the very same Ponmudi hills, by stating that 41 individuals were from 300-365 m, 9 from 110-300 $\mathrm{m}, 5$ from $365-650 \mathrm{~m}$, and thus restrict the limit to a comparatively lower altitudinal range $(110-650 \mathrm{~m}$ a.s.1.) despite surveying the entire hill range, up to $>1000 \mathrm{~m}$ a.s.l. In the present study, sightings have been recorded from elevations as high as $1018 \mathrm{~m}$ a.s.1., well off the mark ( of $650 \mathrm{~m}$ ) given by Inger $e t$ al. (1984). In this study, specimens have been recorded from three broadly classified vegetation types namely, rainforest, moist deciduous forest and Myristica swamp forest which is in accordance with literature (Das, 2002; Inger et al., 1984; Jose et al., 2007). Daniels (1991) states that several individuals were encountered in Balmore (500 $\mathrm{m}$ a.s.1.), without mentioning any frequency, and a female was sighted at Maramalai hills (400 $\mathrm{m}$ a.s.l.) in Kanyakumari district of Tamil Nadu State. Regarding substrate-utilization, my analysis revealed that leaf litter was preferred the most, but sightings have also been recorded from rocks, fallen $\operatorname{logs}$, tree base, shrubs and bare ground. Though this species is primarily regarded as terrestrial, sightings on other substrates such as tree trunks, even at a height of $1.5 \mathrm{~m}$ above ground level, have been reported earlier (Inger et al., 1984). Also, Das (2002) states that, "rarely, it occurs in low vegetation such as shrubs and tree trunks". This study is in accordance with Inger et al., (1984) and Daniels (1991) regarding substrate preference i.e., most of the individuals were on leaf litter, all of which are highly consistent with my records. The maximum extent of habitat disturbance observed during the study was primarily due to the pressure exerted by tourism activities. Collection of leaflitter from the forests by the Forest Department staff for burning fire-lines may affect this species, which is a habitat specialist, since maximum sightings were from leaf litter and minimum was from bare ground. This observation strongly infers that leaf litter may be the potential foraging substrate for this species, but considerable further research work is needed to confirm this statement. Also, the intrusion of tea plantations into forests has led to removal of canopy cover. More recently, this was also noted by Jose et al. (2007). However, the present record from cardamom plantations, where shrub layer homogeneity was the only resultant habitat disturbance, confirms its stenotopic trait. Though an anthropogenic habitat, cardamom plantation resembles the physiognomy of natural, climax vegetation types very well and thus, was observed to have a good amount of leaf litter unlike tea plantations. Elsewhere, other stenotopic, endemic, arboreal agamids were also sighted in cardamom/coffee plantations (pers. obs.). Predominantly terrestrial habit of juvenile Calotes elliotti reported here is in accordance with the observations of Brown (1992) in its congener $C$. versicolor. 


\section{Acknowledgements}

This work was the dissertation project of my M.Sc degree in Wildlife biology, with K. Thenmozhi being the guide. I thank Kerala Forest Department; Ouseph (Chief Conservator of Forests), Pradeep Kumar (Divisional Forest Officer), Ajith and Asokan (Forest Range Officers, Palode Range); Martin and Gopan (Forest Guards) for permission and support, Srinivasan and the administration of Merchiston Estate for their hospitality. I am grateful to K. Thiyagesan, R. Nagarajan and J. Pandiyan of my college's Zoology Department and P. Kannan and S.R. Ganesh of Chennai Snake Park for their comments and suggestions during study design and manuscript preparation. Finally, I would like to thank Prof. Upali Amarasinghe (University of Kelaniya, Sri Lanka) for reviewing the statistical analysis.

\section{Literature cited}

Bhupathy, S. and P. Kannan, 1997. Status of Agamid lizards in the Western Ghats. Technical Report No. 5. Salim Ali Centre for Ornithology and Natural history, Coimbatore: 27.

Brown, S., 1992. Microhabitat relations of some snakes and lizards in Tamil Nadu, South India. Hamadryad, 17: 35-38.

Buhle, M., 1983. Haltung, Nachzucht und Verhaltensweise von Otocryptis wiegmanni Wagler, 1830. Sauria, 5 (1): 5-10.

Campbell, H. W. and S. P. Christman, 1982. Herpetological communities. Wildlife research report 13. U. S. Department of the interior and Fish and Wildlife service. Washington D.C.: 193-200.

Daniels, R. J. R., 1991. Ecology and status of little known lizard, Otocryptis beddomii Boulenger. Cobra, 5: 3-4.

Das, I. 2002. A Photographic guide to Snakes and other Reptiles of India. New Holland Publishers, U. $\mathrm{K}: 144$.

Inger, R. F., H. B. Shaffer, M. Koshy and R. Bakde, 1984. A report on a collection of amphibians and reptiles from the Ponmudi, Kerala, South India. Journal of the Bombay Natural History Society, 81 (2): 551-570.

Ishwar, N. M., R. Chellam, A. Kumar and B. R. Noon, 2003. The Response of Agamid lizards to Rainforest fragmentation in Southern Western Ghats, India. Wildlife Conservation and Society. 1, 2 Sage Publications, New Delhi/Thousand Oaks/London: 6986.
Jose, J., K. K. Ramachandran and P. V. Nair, 2007. A rare and little known lizard Otocryptis beddomii from the Myristica swamps of Southern Kerala, India. Herpetological Bulletin, 101:27-31.

Kumar, A., R. Chellam, B. Choudary, D. Mudappa, K. Vasudevan, N. M. Ishwar and B. R. Noon, 2001. Impact of rainforest fragmentation on small mammals and herpetofauna in the Western Ghats, South India. Report of WII, SACON and U. S. Fish and Wildlife Service: 28.

Manthey, U., 1981. Die Echsen des ceylonesischen Regenwaldes und seiner Randgebiete. Sauria, 3 (2): 25-35.

Manthey, U., 1985. Otocryptis wiegmanni Wagler. Sauria, 7 (2, Suppl.): 11-12.

Matuschka, F. R., 1978. Beobachtungen bei der Haltung von Otocryptis wiegmanni (Reptilia: Sauria: Agamidae). Salamandra, Frankfurt/M, 14 (4): 207211.

Molur, S. and S. Walker (Eds). 1998. Reptiles of India Report summary, CAMP workshop. Zoos'Print XIII: 7.226 .

Murthy, T. S. N., 1980. Recent rediscovery of the rare agamid lizard Otocryptis beddomii. Journal of the Bombay Natural History Society, 77 (2): 343-344.

Murthy, T. S. N., 1985. A Field guide to the lizards of Western Ghats. Occasional Paper 72. Zoological Survey of India, Calcutta: 124.

Sasidharan, N. K., 2004. Working plan (2004 - 2013), Thiruvananthapuram Forest Division. Kerala Forest Department.

Smith, M. A., 1935. The fauna of British India, including Ceylon and Burma: Reptilia and Amphibia, vol.2 - Sauria. Taylor \& Francis, London: 440. 


\section{PLATE 5}

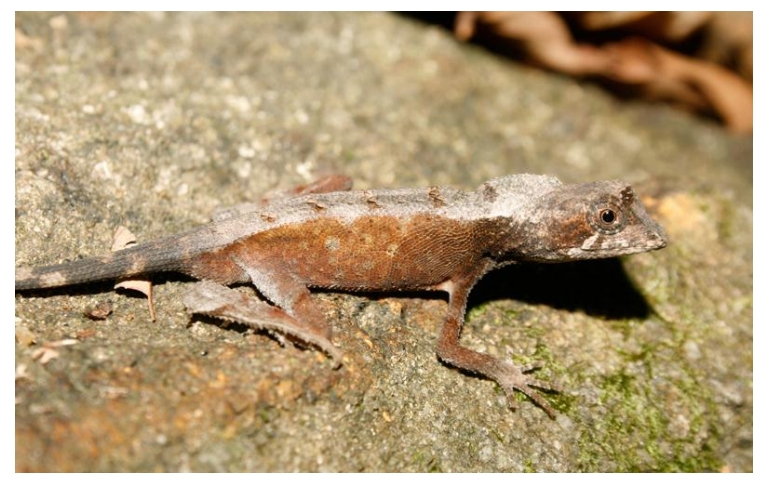

Fig. 01: An abnormal adult male showing bilaterally compressed dorsal ridge with nuchal depression

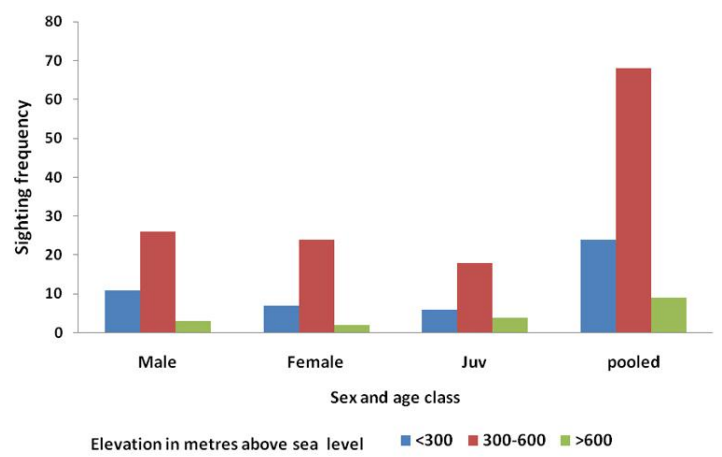

Fig. 03: Altitudinal distribution of Otocryptis beddomii

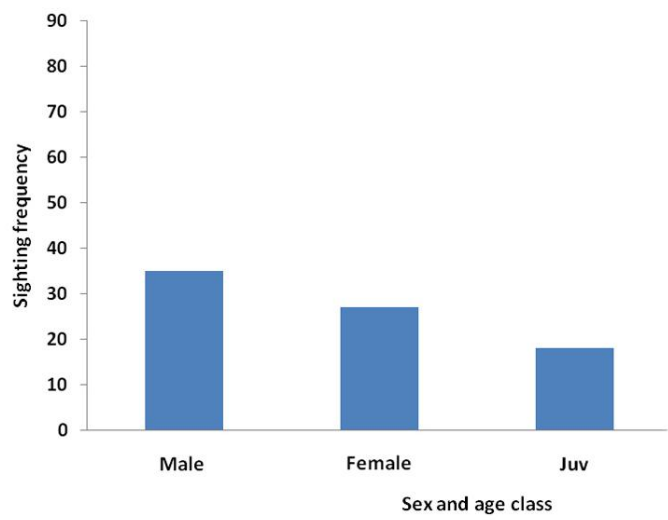

Fig 05a: Sightings on leaf litter

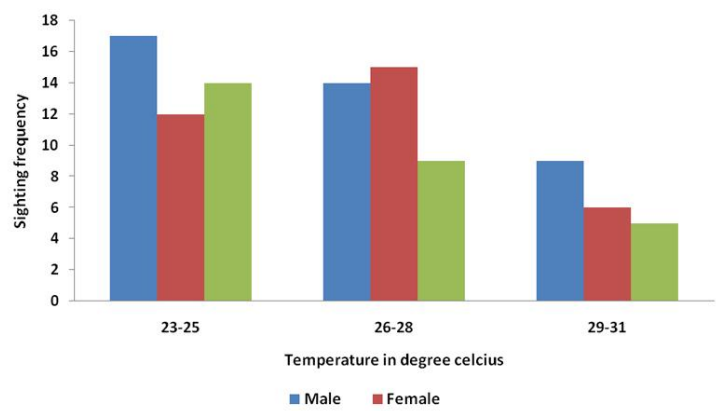

Fig. 06: Temperature vs. sighting frequency

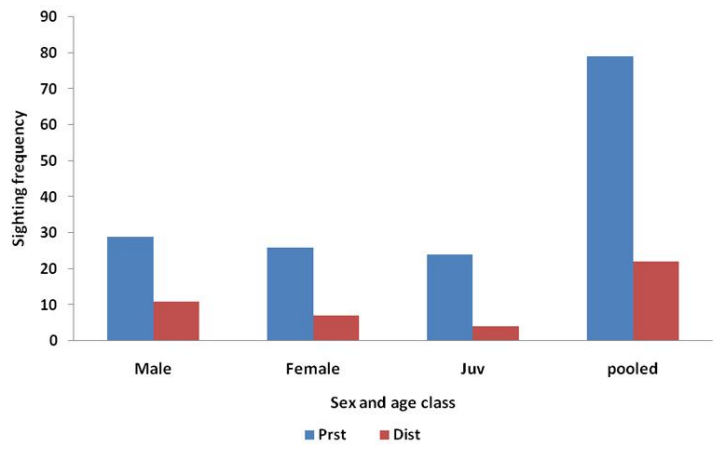

Fig. 02: Distribution of Otocryptis beddomii in different qualities of habitat

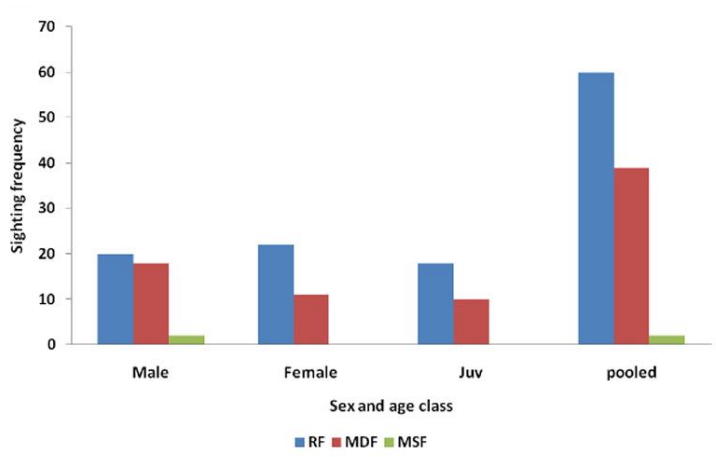

Fig. 04: Sighting frequency vs. habitat types

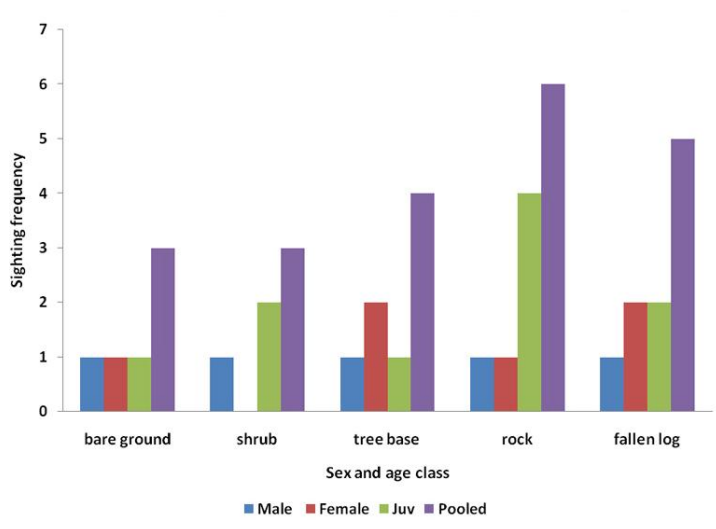

Fig. 05b: Sightings on other substrates

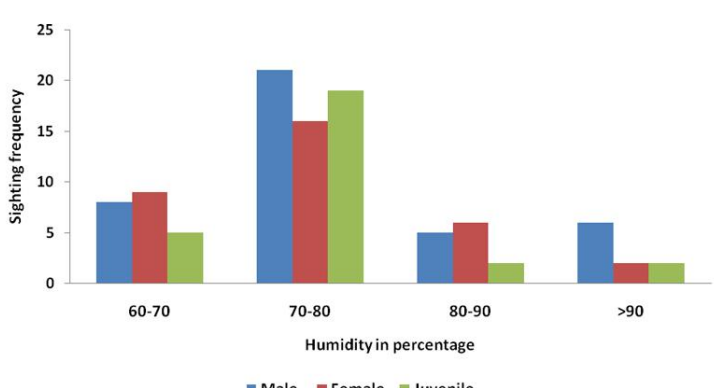

Fig. 07: Humidity vs. sighting frequency 